\title{
Sildenafil Citrate ( Viagra) effect on the pattern of controlled hypotension induced by sodium nitroprusside or nitroglycerin
}

\author{
Mona M. Radwan and Nemat El Baz Mohamed \\ Department of Pharmacology, Faculty of Medicine for Girls Al-Azhar \\ University, Cairo
}

\begin{abstract}
:
Oral sildenafil Citrate (viagra) is an effective treatment for erectile dysfunction (ED) . There are reports of serious hypotension when sildenafil citrate is given to patients taking certain vasodilators. This study was designed to assess the effects of sildenafil citrate (viagra) therapy on the dose, efficacy and safty of I.V. infusion of nitrovasodilators; sodium nitroprusside or nitroglycerin, to induce controlled "delibrate" hypotension (55-60 $\mathrm{mmHg}$ ). Sodium nitroprusside (SNP; $1 / \mathrm{ug} / \mathrm{kg} / \mathrm{min}$ ) or nitroglycerin (NTG. $2 \mathrm{ug} / \mathrm{kg} / \mathrm{min}$.) was intravenously given to induce hypotension in control cats and in cats treated with sildenafil $(1.9 \mathrm{mg} / \mathrm{kg})$ single oral dose. Some heamodynamic variables; mean arterial blood pressure "MAP" and "ECG" pattern, were monitored.

In control groups it was found that, ( SNP) infusion achieved a rapid induction of controlled hypotension accompanied by reflex hypertension after drug infusion discontinuation. However, (NTG) infusion failed to decrease the (MAP) to the target level, and upon discontinuation of its infusion, return of arterial blood pressure to control values, was moderately slower. Comparison between the effect of the two drugs revealed a significant difference in mean arterial blood pressure after infusion.

Treatment with sildenafil citrate (viagra), augmented the (MAP) reduction caused by (SNP), and improved the lack of potency of (NTG) induced hypotension . Comparison between the effect of the two drugs revealed a significant difference during drug infusion, and after drug infusion discontinuation. Doses of (SNP) or (NTG) required to induce delibrate hypotension in groups treated with sildenafil were decreased when compared to that in control groups.

Sodium nitroprusside (SNP) infusion induced increase in the mean heart rate (HR) without ECG changes in control or treated groups. Sildenafil citrate treatment increased significantly the initial HR in comparison to control group. In contrast, nitroglycerin (NTG) infusion, did not change significantly the (HR) in control group. However, in sildenafil citrate treated group, (NTG) infusion induced significant increase in the HR throughout the study, and there was also changes in PR QRS, and QT interval in one case.
\end{abstract}

\section{Introduction:}

Induced "controlled, deliberate" hypotension, as an adjunct to anest hesia, is frequently used to minimize blood loss and to improve the quality of the surgical field (Sivarajan et al., 1980). Cottrell et al. (1980) reported that, most reviews suggests an MAP of $50-60 \mathrm{mmHg}$, as the lower limit of blood pressure while using the technique of induced hypotension. Sodium nitroprusside (SNP) and nitroglycerin (NTG) have been used to induce hypotension because they are rapid in onset and have short duration of action (Friederich and Butterworth, 1995). The vasodilator effect of both (SNP) and (NTG) is mediated by a release of nitric oxide (NO), which 
diffuses into vascular smooth muscle and mediates vasodilation by stimulating soluble guanylate cyclase to produce guanosine 3'-5 cyclic monophosphate (cGMP) , thereby causing smooth muscle relaxation (Ignarro et al. 1983 and Ignarro, 1989) . cGMP and cAMP are inactivated by phosphodiesterases by hydrolytic cleav -age of the 3'-ribosephosphate bond. More than nine different families and subfamilies of phosphodiesterases; phosphodiesterase PDE2, PDE3. PDE4, PDE5 that differ in their spec ificity, have been identified (Kuthe et al.,1999). Beavo, (1995) reported that type 5 phosphodiesterase (PDE5) is abundant in human circulation.

The introduction of effective oral treatment of erectile dysfunction (ED) by means of agents with a peripheral (sildenafil) or central (apomorphine) site of action has occurred as a result of active research on the mechanisms of erection (Anderson, 1993, Anderson and Wagner, 1995, McKenna, 1998). Sildenafil citrate "viagra", which has been recently introduced into clinical practice for the treatment of erectile dysfunction, is a selective inhibitor of type 5 phosphodierterase (Jeremy et al.,1997) . After oral administration, Moreland, et al. (1999) found that blood sildenafil level peaked in 60-120 minutes, and its plasma half-life was estimated to be 4-4.5 hours. The effects of sildenafil are in part mediated by enhancing the action of nitric oxide and accompanied by a fall in systemic blood pressure (Mahmud et al., 200l). The blood pressure-lowering effect of sildenafil did not differ significantly in the normotensive and hypertensive patients (Vardi et al., 2002).

Therefore, there may be a potential interaction between sildenafil and (NO) donors, used for induction of controlled hypotension. So, this study was designed to evaluate the effects of sildenafil citrate treatment on some (SNP) and (NTG) heamodynamics in cats; mean arterial blood pressure (MAP) and ECG pattern.

\section{Materials And Methods:}

Drugs used in this study were: sildenafil citrate (Viagra $50 \mathrm{mg}$ tablet; Pfizer, Egypt), sodium Nitroprusside dihydrate (Nipride $50 \mathrm{mg}$ vial ; Warwick U.K.), and Nitroglycerin (Tridil $5 \mathrm{mg} / \mathrm{ml}$ vial, Merck pharma).

Doses corresponding to human therapeutic doses were calculated according to the method reported by Paget and Barnes (1964) and statistical analysis of the data was performed by student " $t$ " test of significance.

Mean arterial pressure $(\mathrm{MAP})=$ diastolic + (systol-diastol/3) $\mathrm{mmHg}$. Heart rate ( beats/min.) was also calculated from the recorded ECG.

\section{Methods:}

Four groups of cats, each of six animals were used. The first group was treated with intravenous infusion (I.V.I.) of sodium nitroprusside (1 $\mathrm{ug} / \mathrm{kg} / \mathrm{min}$.), and the second group with I.V.I. of nitroglycerin (2 $\mathrm{ug} / \mathrm{kg} / \mathrm{min}$.) Both infusions were titrated as needed to achieve the target (MAP) 55-60 mmHg. Heamodynamic informations collected for both drugs included MAP ; before, during, and after drug infusion discontinuation, drug requirement ( $\mathrm{ug} / \mathrm{kg}$ ), and ECG ( lead II) changes. These two groups were considered as control groups .

The third and fourth groups were treated with sildenafil citrate " viagra" $(1.9 \mathrm{mg} / \mathrm{kg})$ single oral dose one hour before experiment. Animals in the third group were given (SNP), and the fourth group were given (NTG), in the same way mentioned in the first and second 
groups. The same parameters mentioned above were recorded and compared with that of the control groups.

\section{Results:}

\section{Effect on mean arterial pressure} (MAP):

Sodium nitroprusside (SNP) was successful and rapid in achieving a significant decrease in the MAP to the target level $(55-60 \mathrm{mmHg})$ from base line values as shown in (Table 1, Figs. 1,2). Rapid return of blood pressure with reflex increase was observed after its infusion discontinuation. The average dose required to induce the decrease in blood pressure was 300-350 $\mathrm{ug} / \mathrm{kg}$. On the other hand (NTG) infusion showed a slow decrease and failed to induce the target decrease in the MAP ( Table 1, Figs. 1,3). Slow repound of blood pressure without reflex hypertension after (NTG) infusion discontinuation, was observed . The average dose required to induce the decrease in blood pressure was 200$400 \mathrm{ug} / \mathrm{kg}$. Table 1 and Fig. 1 shows the comparison between (SNP) and (NTG) effects on mean arterial pressure .

Sildenafil citrate "viagra" (1.9 $\mathrm{mg} / \mathrm{kg}$ ) oral treatment, augmented significantly the decrease in MAP induced by (SNP) or (NTG) infusion (Table 2 , Figs. 4,5,6). Fig. (7) shows the mean arterial pressure of (SNP) and (NTG) in control and sildenafil treated groups.

Table (1): Mean arterial pressure (MAP) $\mathrm{mmHg} \pm$ SEM values before, during, and after discontinuation of SNP (1ug/kg/min.) or NTG ( $2 \mathrm{ug} / \mathrm{kg} / \mathrm{min}$.) infusion, in control cats.

\begin{tabular}{|c|c|c|c|c|c|c|c|c|}
\hline \multirow{3}{*}{ Group } & \multicolumn{7}{|c|}{ Mean arterial pressure (MAP) $\mathrm{mmHg} \pm \mathrm{SEM}$} & \multirow{3}{*}{$\begin{array}{c}\text { Drug } \\
\text { requirement to } \\
\text { induce } \\
\text { hypotension }\end{array}$} \\
\hline & \multirow{2}{*}{$\begin{array}{c}\text { Before } \\
\text { infusio } \\
n\end{array}$} & \multicolumn{3}{|c|}{ During infusion } & \multicolumn{3}{|c|}{ After infusion } & \\
\hline & & $1 \mathrm{~min}$. & $2 \min$. & 3 min. & 2 min. & 4 min. & $8 \mathrm{~min}$. & \\
\hline \multirow{3}{*}{$\begin{array}{r}\text { SNP } \\
\quad \text { Mean } \\
\pm \text { SEM }\end{array}$} & & & & & & & & \\
\hline & 82.5 & $55.5^{*}$ & $54.75^{*}$ & $53.75^{*}$ & $61.75^{*}$ & 81.25 & $90.5^{*}$ & $300-350 \mathrm{ug} / \mathrm{kg}$ \\
\hline & 0.96 & 1.85 & 0.48 & 0.48 & 1.11 & 2.75 & 1.26 & \\
\hline \multirow{3}{*}{$\begin{array}{r}\text { NTG } \\
\quad \text { Mean } \\
\pm \text { SEM }\end{array}$} & & & & & & & & \\
\hline & 84 & $73.25^{* \circ}$ & $68^{* \circ}$ & $63.25^{* \circ}$ & $67.75^{* \circ}$ & $71.5^{* \circ}$ & $75.75 * \circ$ & $200-400 \mathrm{ug} / \mathrm{kg}$ \\
\hline & 0.82 & 1.44 & 1.1 & 1.25 & 1.32 & 1.32 & 1.49 & \\
\hline
\end{tabular}

* Significant difference between the MAP values caused by SNP or NTG in comparison to the initial values.

${ }^{\circ}$ Significant difference between the MAP caused by NTG when compared to that caused by SNP. 
Sildenafil Citrate ( Viagra) effect.....

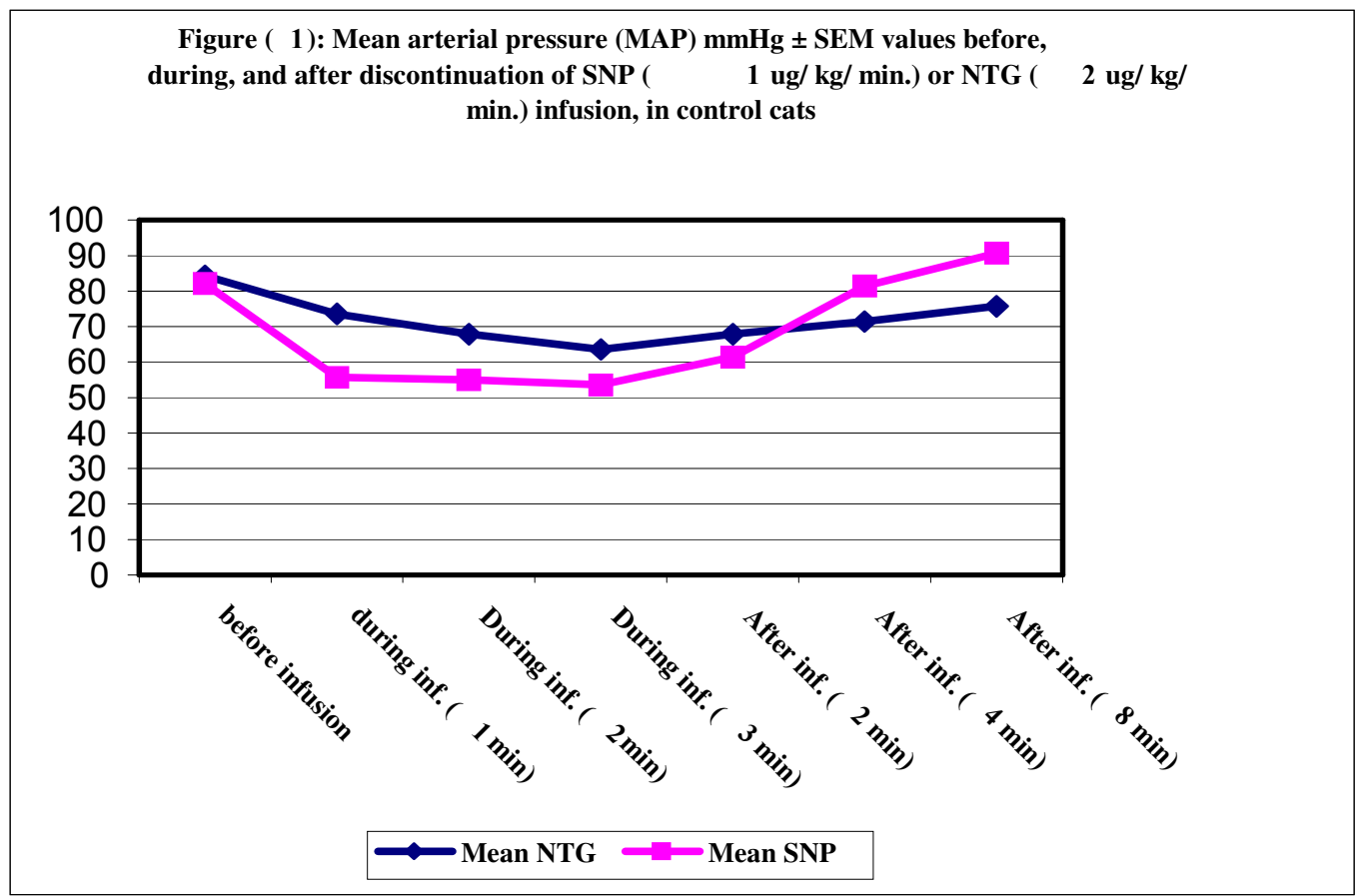

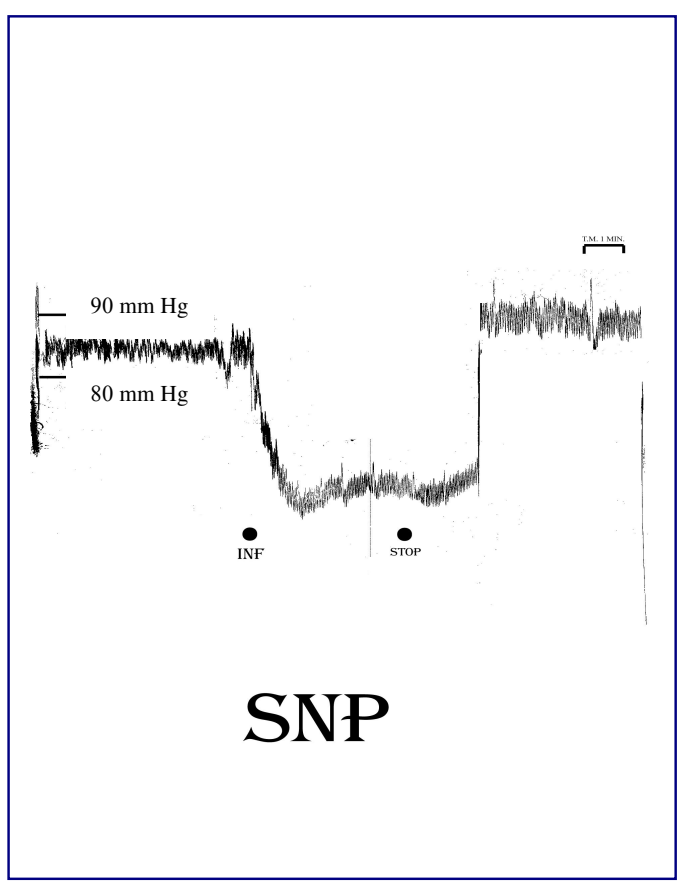

Fig. (2) : Controlled hypotension induced by sodium nitropresside (SNP) $(1 \mu \mathrm{g} / \mathrm{kg} / \mathrm{min}$.) infusion in control cats.

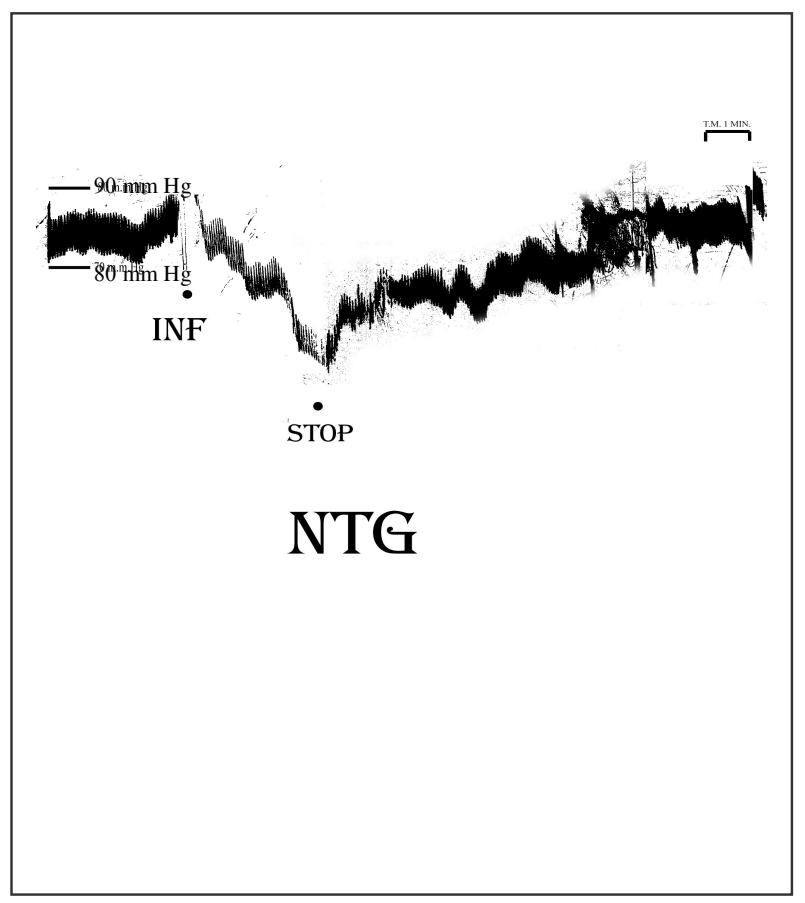

Fig. (3) : Controlled hypotension induced by nitroglycerin (NTG) ( $2 \mu \mathrm{g} / \mathrm{kg} / \mathrm{min}$.) infusion in control cats. 
Table (2): Mean arterial pressure (MAP) $\mathrm{mmHg} \pm$ SEM values before, during, and after discontinuation of SNP (1ug/kg/min.) or NTG (2 ug/ $\mathrm{kg} / \mathrm{min}$.) infusion, in sildenafil citrate "viagra" $(1.9 \mathrm{mg} / \mathrm{kg})$ treated cats.

\begin{tabular}{|c|c|c|c|c|c|c|}
\hline \multirow{3}{*}{ Group } & \multicolumn{5}{|c|}{ Mean arterial pressure (MAP) $\mathrm{mmHg} \pm$ SEM } & \multirow{3}{*}{$\begin{array}{c}\text { Drug } \\
\text { requirement to } \\
\text { induce } \\
\text { hypotension }\end{array}$} \\
\hline & \multirow{2}{*}{$\begin{array}{c}\text { Before } \\
\text { infusion }\end{array}$} & \multirow{2}{*}{$\begin{array}{c}\text { During } \\
\text { infusion } \\
1 \mathrm{~min} .\end{array}$} & \multicolumn{3}{|c|}{ After drug discontinuation } & \\
\hline & & & 2 min. & 4 min. & 8 min. & \\
\hline \multicolumn{7}{|l|}{ SNP } \\
\hline Mean & 82.25 & $23.5^{*}$ & $63.25 *$ & 81.75 & $97.5 *$ & $60-70 \mathrm{ug} / \mathrm{kg}$ \\
\hline & 1.18 & 0.87 & 2.25 & 2.25 & 0.87 & \\
\hline \multicolumn{7}{|l|}{ NTG } \\
\hline $\begin{array}{l}\text { Mean } \\
\pm \text { SEM }\end{array}$ & 84.5 & $56^{* \circ}$ & $62 *$ & $71.25 * \circ$ & $80.25 * 0$ & $100-200 \mathrm{ug} / \mathrm{kg}$ \\
\hline & 1.26 & 0.58 & 1.08 & 1.25 & 0.63 & \\
\hline
\end{tabular}

* Significant difference between the MAP values caused by SNP or NTG in comparison to the initial values.

${ }^{\circ}$ Significant difference between the MAP caused by NTG when compared to that caused by SNP

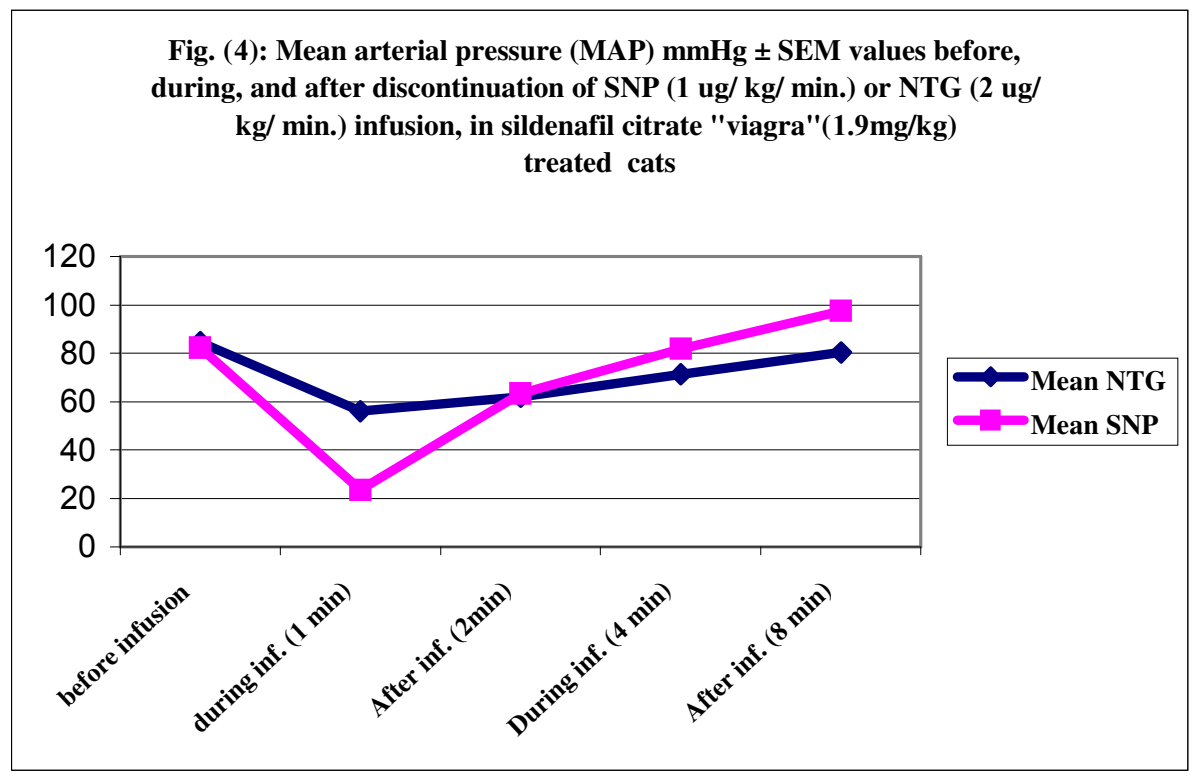




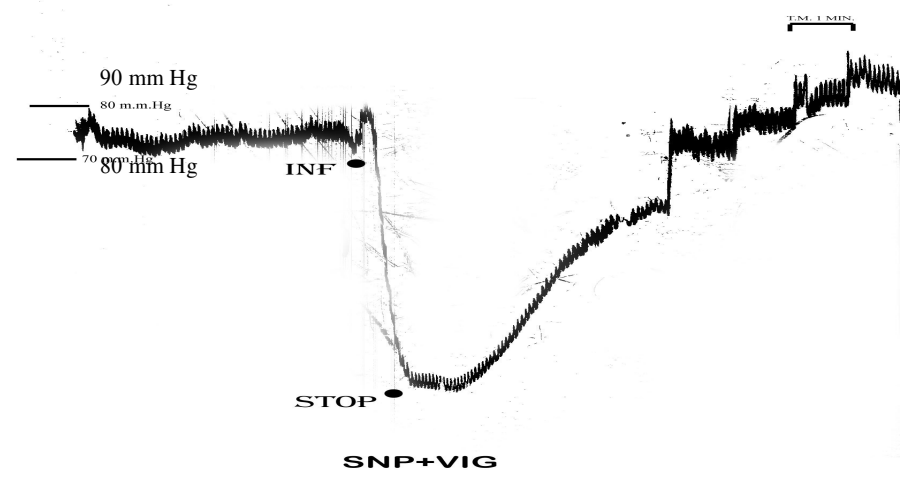

Fig. (5): Controlled hypotension induced by ( SNP) ( lug/kg/min.) infusion in sildenafil citrate "viagra" ( $1.9 \mathrm{mg} / \mathrm{kg}$ ) single oral dose treated cats.

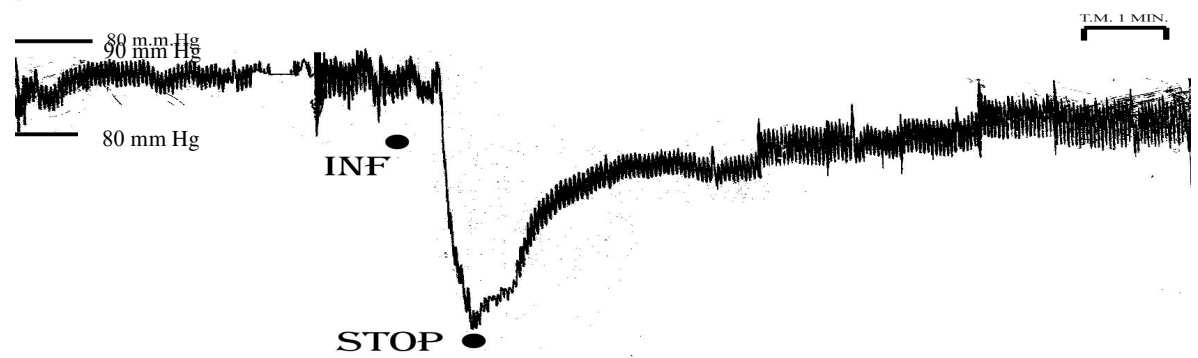

NTG+VIG

Fig. (6) : Controlled hypotension induced by (NTG) ( $2 \mathrm{ug} . \mathrm{kg} / \mathrm{min}$.) infusion in sildenafil citrate "Viagra" $(1.9 \mathrm{mg} / \mathrm{kg})$ single oral dose treated cats.

Fig. (7): Mean arterial pressure (MAP) $\mathrm{mmHg} \pm$ SEM values before, during, and after discontinuation of SNP ( $1 \mathrm{ug} / \mathrm{kg} / \mathrm{min}$.) or NTG ( $2 \mathrm{ug} /$ $\mathrm{kg} / \mathrm{min}$.) infusion, in control and sildenafil citrate $(1.9 \mathrm{mg} / \mathrm{kg})$ pretreated cats:

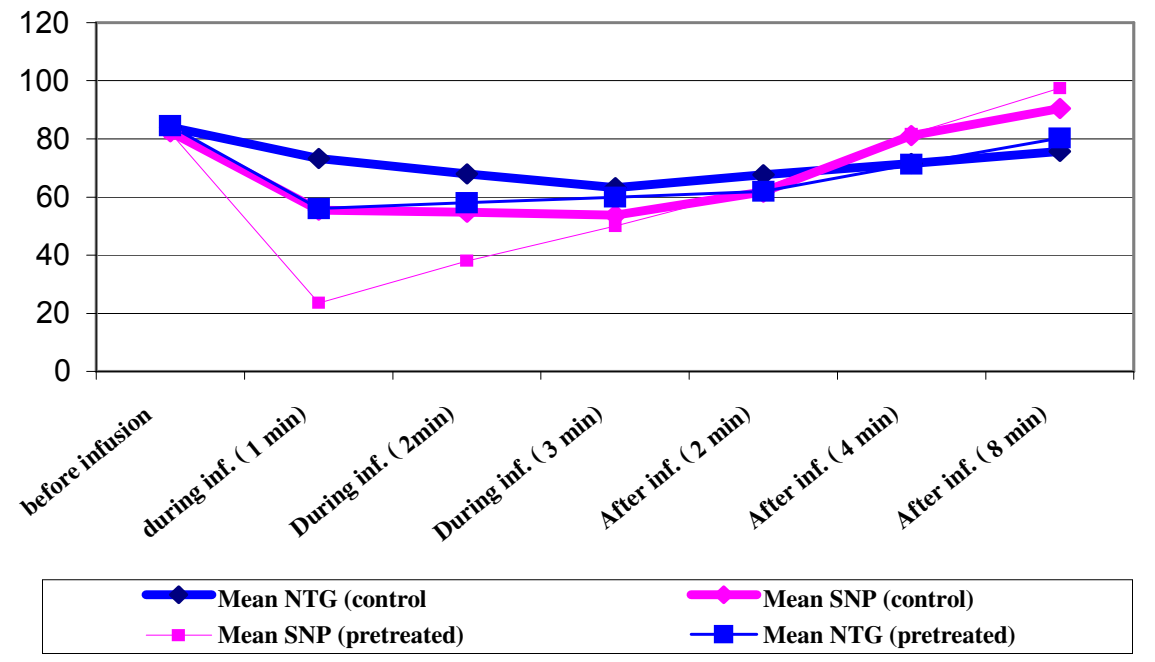




\section{Effect on heart rate (HR) and ECG pattern}

In control groups (SNP) infusion induced significant reflex increase in (HR), in contrast to (NTG) infusion which caused insignificant change in (HR). Normal PR, QRS, and ST pattern were recorded in both groups (Table 3 , Fig. 8).

Sildenafil citrate treatment caused significant increase in the initial
(HR) of (SNP ) and (NTG) groups . In (SNP) group there was no change in (HR) throughout the infusion. However, in (NTG) group sildenafil treatment caused significant increase in (HR) (Table 3, Fig. 8 ). There was also changes in PR, QRS and QT intervals in one case.

Table (3): Effect of treatment with Sildenafil citrate (viagra) $(1.9 \mathrm{mg} / \mathrm{kg})$ on mean heart rate (HR) beats $/ \mathrm{min}, \pm \mathrm{SEM}$ caused by SNP (1ug/kg/min) or NTG $(2 \mathrm{ug} / \mathrm{kg} / \mathrm{min})$ infusion.

\begin{tabular}{|c|c|c|c|c|}
\hline Groups & Initial & $\begin{array}{r}\text { Mean HF } \\
\text { during targ } \\
\text { Arterial pre }\end{array}$ & $\begin{array}{l}\text { after drug } \\
\text { liscontinuation }\end{array}$ & Changes \\
\hline $\begin{array}{r}\text { Control } \\
\text { SNP } \\
\text { NTG } \\
\text { Sildenafil } \\
\text { treated } \\
\text { SNP } \\
\text { NTG }\end{array}$ & $\begin{array}{l}300 \pm 7.1 \\
300 \pm 7.1\end{array}$ & $\begin{array}{l}430 \pm 7.1^{*} \\
310 \pm 7.1^{\circ} \\
430 \pm 7.1^{*} \\
355 \pm 7.1^{*} \bullet\end{array}$ & $\begin{array}{l}375 \pm 7.1^{*} \\
300 \pm 7.1^{\circ}\end{array}$ & $\begin{array}{l}\text { Normal RR, QRS, ST } \\
\text { Normal RR, QRS, ST } \\
\\
\text { Normal RR, QRS, ST } \\
\downarrow \text { PR }(0.06 \mathrm{sec}), \downarrow \text { QRS } \\
(0.04 \mathrm{sec}), \text { prolonged QT } \\
\text { interval in one case }\end{array}$ \\
\hline
\end{tabular}

*Significant difference between the mean HR values caused by SNP or NTG in comparison to the initial values.

- Significant difference between the mean HR values caused by NTG when compared to that caused by SNP.

- Significant difference in mean HR of cats in treated groups when compaired to that in control groups

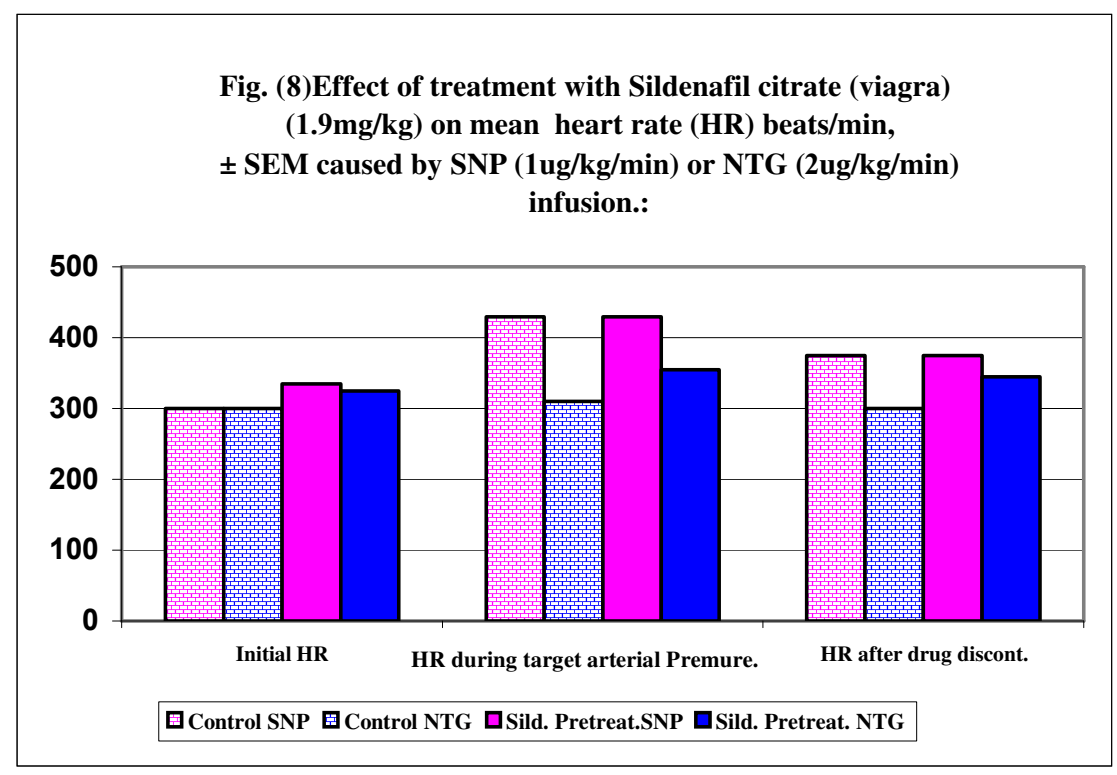




\section{Discussion:}

Nitric oxide doners; (SNP) and (NTG), are often used to induce deliberate hypotension. However, each drug alone is associated with its own limitations, such as cyanide poisoning with (SNP) large doses (Friederich and Butterworth, 1995), and 1ack of potency with (NTG) (Porter et al., 1988).

This study demonstrated that (SNP) infusion was successful in achieving the target decrease in (MAP). However this effect was accompanied by rebound hypertension after abrupt discontinuation of its infusion. In contrast, (NTG) infusion failed to decrease the blood pressure to the target level, and upon discontinuation of its infusion, return of arterial pressure to control values was moderately slower. This results shows conformity with the study of Yaster et al. (1986) who reported that (SNP) was the agent of choice for the reliable and sustained induction of deliberate hypotension, however, (NTG) was ineffective as an agent to produce rapid predictable and sustained decrease in arterial pressure below $55 \mathrm{mmHg}$. The authors attributed the effect of (SNP) to its action on both resistance and capacitance vessels, whereas (NTG) is thought to affect primarily the venous capacitance vessel.

Sildenafil citrate "viagra"; phosphodiesterase type 5-inhibitor, is currently used to treat erectile dysfunction (ED) in millions of patients (Goldstein et al., 1998). Previously, a synergistic interaction between sildenafil and (NO) doners , has indeed been demonstrated in isolated human vessels (Medina et $a l ., 2000)$, in patients with stable angina (Webb et al., 2000), as well as in isola ted rabbit aorta (Wallis et al.,1999).

In the present study, we investi gated the effect of sildenafil treatment on (SNP) and (NTG) induced hypote nsive effect. The results demonstrated that, sildenafil treatment augmented the effect of (SNP) infusion and caused life-threatening hypotension within one minute. In contrast, the lack of potency of (NTG) infusion, was significantly enhanced by sildenafil. The dose required to induce hypoten -sion by both drugs was reduced.

The most common adverse events of sildenafil such as headache and hypotension, results from its vasodila ting properties (Rosenkranz and Erdmann, 200l) . The authors reported that, the concomitant use of sildenafil and organic nitrates is contraindicated because it may lead to a potentiation of the decrease in blood pressure and cause life-threatening hypotension. Sakuma et al. (2002) reported also that, the relaxant effect of the vasodilators with an (NO) donor property, was significantly enhanced, and the cGMP level of the tissue was elevated, after adding sildenafil . Sildenafil alone increased the plasma cGMP concentr ations (37\%-40\% over the basal) which was augmented by (SNP) (60\%) over the value achieved by sildenafil alone (Yoo et al., 2002). A synergistic interaction between (NTG) and sildenafil was also observed in consci ous chronically instrumented dogs by Schwemmer et al. (200l). The intera ction between sildenafil and (NTG), furthermore, was not affected by the route of administration of the two drugs (Webb et al., 2000).

With regards to the effect of (SNP) or (NTG) infusion on the ECG of cats in the present study, (SNP) exhibited significant reflex increase in (HR) of cats in both control and treated groups, whereas sildenafil increased significantly only the initial (HR) in the treated group. In contrast (NTG) induced insignificant effect in (HR) of 
cots in the control group, while in sildenafil treated group, (NTG) infusion increased signifciantly the (HR) throughout the study. Phillips et al. (2000) have demo -nstrated that sildenafil increases the sympathetic neural activity in humans.

It is likely that the increase in the initial (HR) of cats induced by sildenafil may reflect a positive inotropic effect, induced by sildenafil therapy (Yoo et al.,2002). Furthermore this tachycardia can be explained by an acute activation of the baroreflex control mechanism, which follows the decrease of blood pressure and buffers it around the new level of set point (Young et al.,1984).

In conclsuion sildenafil citrate "viagra', which has been recently introduced into clinical practice for treatment of erectile dysfunction, is a selective inhibitor of type 5-phospho diesterase. Sodium nitroprusside (SNP) and nitroglycerine (NTG), are often used to induce deliberate hypote -nsion (50-60 mmHg). However, each drug is associated with its own limitat -ions as cyanide poisoning with (SNP) large doses, and lack of potency with (NTG). The vasodilator effect of (SNP) or (NTG) is mediated by the release of (NO) which mediates vasodilation by stimulating the production of cGMP . Therefore ,there may be a potential interaction between sildenafil and (NO) doners in the systemic circulation where type 5 phosphodiesterase is abundant.

We observed that, (SNP) induced hypotension was augmented by sildenafil, and the lack of potency (disadvantage) with (NTG) was impro ved. The doses of both drugs required to induce deliberate hypotension was decreased after sildenafil treatment .

So we suggest that the use of sodium nitroprusside to induce hypote nsion during anesthesia in combination with sildenafil can be limited by the risk of marked vasodilation unless the dose is decreased and hence the potential for cyanide toxicity. In contrast, the concomitant use of sildenafil and (NTG) may improve the decrease in blood pressure caused by (NTG) infusion.

\section{References:}

1. Andersson KE (1993): Pharmacology of lower Urinary tract smooth muscles and Penile erectile tissues. Pharmacol. Rev. 45: 254

2. Andersson KE. and Wagner G. (1995): Physiology of penile erection. Physiol. Rev. 75: 191.

3. Beavo JA.(1995): Cyclic nucleotide phosphodiesterases: Functional implications of multiple isoforms. Physiol. Rev. 75: 725-48.

4. Cottrell JE., Gupta B., and Turndorf H. (1980): Induced hypotnesion, anesthesia and Neurosurgery. Edited by Cottrell J.E., Turndorf H. St. Louis, CV Mosby; 386-400.

5. Friederich JA and Butterworth $J F$ (1995): I.V. sodium nitroprusside: Twenty years and counting. Anesth Analg.; 81 : 152-62.

6. Goldstein I, Lue TF, Padman -Nathan $H$ et al. (1998): Oral sildenafil in the treatment of erectile dysfunction. N. Engl. J. Med.; 338 : 1397-404 ."Abstract".

7. Ignarro LJ (1989): Biological actions and Properties of endothelium-derived nitric oxide formed and released from artery and vein. Circ. Res., 65: 1-21.

8. Ignarro LJ; Burke TM; Wood KS et al. (1983): Association between cyclic GMP accumulation and acetylcholineelicited relaxation on bovine intrapulmonary artery. J. Pharmacol., Exp. Ther., 228: 682-90.

9. Jeremy JY; Ballard SA and Naylor AM et al. (1997): effects of sildenafil, a type -5cGMP phosphodiesterase inhibitor, and papaverine on cyclic GMP and cyclic AMP levels in the rabbit corpus cavernosum in vitro. Br. J. Urol. 79: 958-63. 
10. Kuthe A.; Stief CG and Magert H.J. et al. (1999): Molecular biological characterisation of phosphodiesterases 3 and 5 in human corpus cavernosum penis [ abstract 405] . Eur Urol. 35 (suppl 2): 102 Abstrract.

11. Mahmud A; Hennessy M. and Feely J. (200l): Effect of sildenafil on blood pressure and arterial wave reflection in treated hypertensive men. J. of Human hypertension, 15(10): 707-13.

12. McKenna KE (l998): Central control of penile erection, Int. J. Impot. Res. 10 (suppl I): S25, Abstract.

13. Medina P., Segarra G., Martinez et al.(2000): Relaxation induced by cGMP phosphodiesterase inhibitors sildenafil and Zaprinast in human vessels. Ann. Thorac. Surg.;70: 1327 31.

14. Moreland RB, Goldstein I, Kin NN et al.(1999): Sildenafil citrate, a selective phosphodiesterase type 5 inhibior: Research and clinical implication in erectile dysfunction. Trends Endocrinol. Metab; 10, 97-104.

15. Paget G.E. and Barnes J.M. (1964): Toxicity test. In : Evaluation of drug activities, pharmacometrics. Edited by Laurence DR and Bacharach AL; Vol. I; Chap. 6; P. 135; Academic Press; London and New York.

16. Phillips B.C.; Kato M., Pesek C.A. et al. (2000): Sympathetic activation by sildenafil. Circulation; 102: 2068 -73.

17. Porter SS, Asher $M$, and Fox DK (1988): Comparison of intravenous nitroprusside, nitroprusside-captopril, and nitroglycerin for deliberate hypotension during posterior spine fusion in adults. J. Clin. Anesth.; I: 8795.

18. Rosenkranz S. and Erdmann E.(200l): Interaction between sildenafil and antihypertensive drugs: What is evidence based? DTsch Med. Wochenschr; 126 (41): 1144-9.

19. Sakuma I., Akaishi Y., Tomioka H. et al. (2002): Interactions of sildenafil with various coronary vasodilators in isolated porcine coronary artery. Eur. J. Pharmacol. 22; 437 (3): 155-63.

20. Schwemmer M; Bassenge, E.; Stoeter M., et al. (2001): Potentiation of sildenafil-induced hypotension is minimal with nitrates generating a radical intermediate. J. Cardiovasc. Pharmacol; 38: 149-55.

21. Sivarajan M.; Amory DW; Everett $G B$ et al. (1980): blood pressure, not cardiac output, determiens blood loss during induced hypotension. Anesth Analg; 59: 203-6.

22. Vardi Y.; Klein L.; Nssar S. et al. (2000): Effects of sildenafil citrate (viagra) on blood pressure in normotensive and hypertensive men. Urology, 59 (5): 747-52.

23. Wallis RM, Corbin JD, Francis SH et al. (1999): Tissue distribution of phosphodiesterase, platelet function, and the contractile responses of trabeculae corneae and Aortic rings in vitro. Am .J. Cardiol.; 83: 3C-12C.

24. -Webb DJ, Muirhead GJ; Wulff M. et. al.(2000): Sildenafil citrate potentiates the hypotensive effects of nitric oxide donor drugs in male patients with stable angina. J. Am. Coll. Cardiol.; 36: 2531.

25. -Yaster M., simmons R.S., R.C.P.T. et al.(l986): A comparison of Nitroglycerin and Nitroprusside for inducing hypotension in children: A double-blind study. Anesth. 65: 175179.

26. Yoo K.Y., Kim . H.S., Moon J. et al. (2002): Sildenafil( Viagra) Augments sodium nitroprusside induced. But not Nitroglycerin-induced hypotension in dogs. Anesth. Analg.; 94: 1505-9.

27. Young M.A.; Watson R.D.S. and Littler W.A. (1984): Baroreflex setting and sensitivity after acute and chronic nicardipine therapy . Clinical Scie; 66, 233-235. 


\title{
Mona M. Radwan \& Nemat El Baz Mohamed
}

\section{تأثير دواء سترات السلندافيل "الفياجرا" على نموذج خفض الدم المقنن الخدث بالصوديوم} نيتروبروسيد أو النيتروجلسرين

\author{
منى محمد رضوان ونعمت الباز محمد \\ قسم الفارما كولوجى - كلية طب البنات - جامعة الأزهر - القاهرة
}

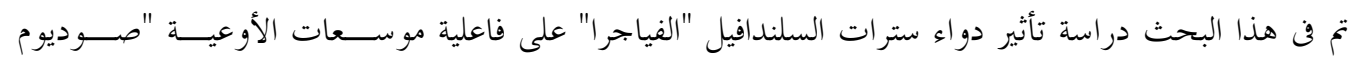

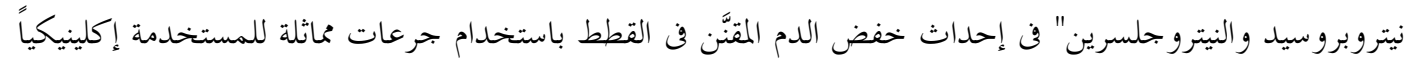
لقياس التغير في متوسط ضغط الدم وسرعة ضربات القبر القلب.

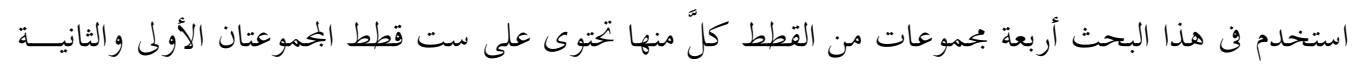

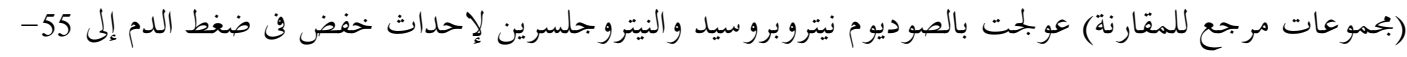

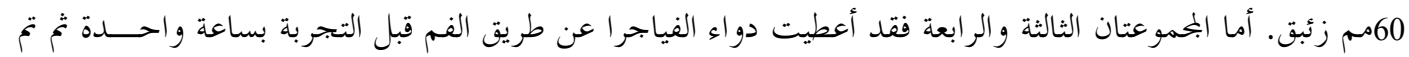

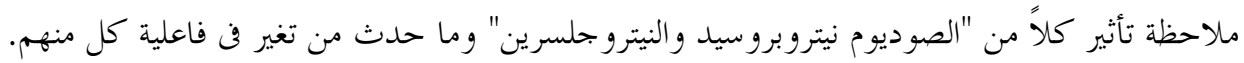

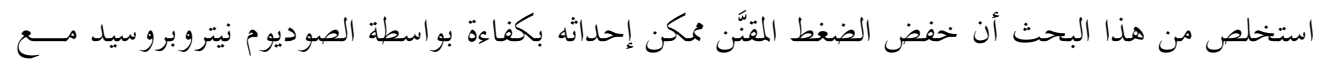

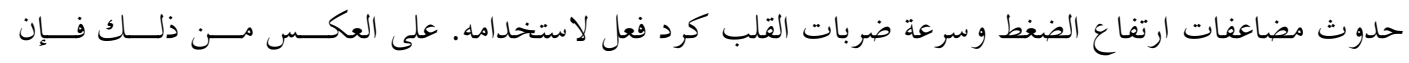

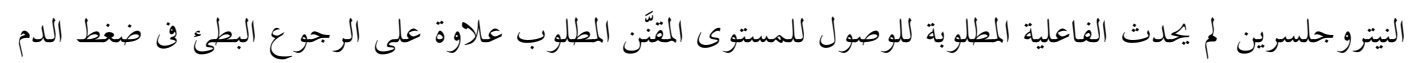
وعدم التغير في ضربات القلب وذلك في بحموعات المقارنة.

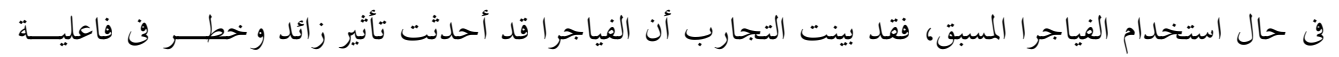

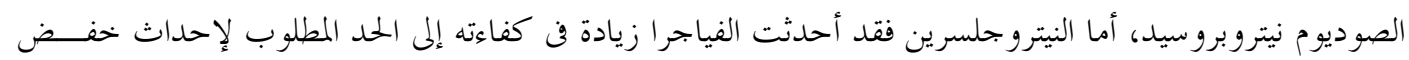

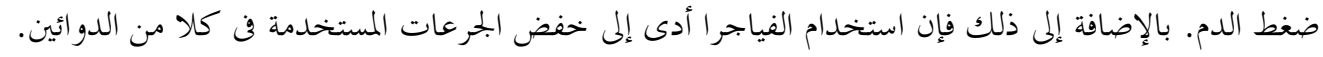

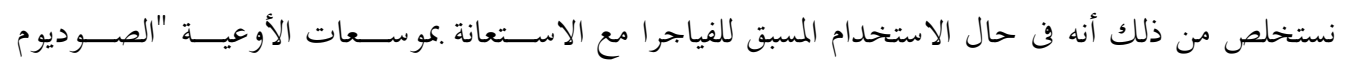

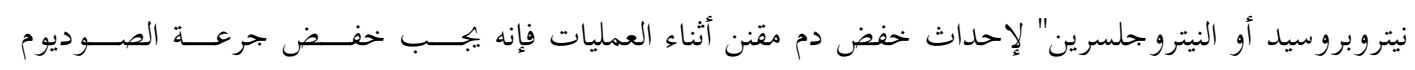

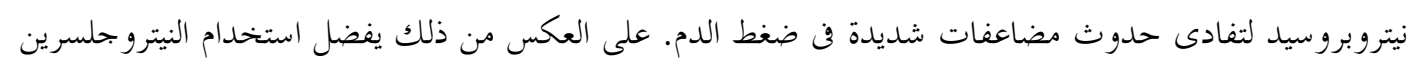
لتحسن كفاوته علاوة على استخدام جرعات صغيرة منه. 